\title{
How Customer Experience Quality Affects Customer Satisfaction-Loyalty with Moderating role of Competitive Choices and Familiarity: Assessment of Private Hospitals in Pakistan
}

\author{
Kashif Abrar $^{1}$, Muhammad Ali Saeed ${ }^{1}$, Israr Ahmad ${ }^{1}$, Sabir Ali $^{1}$
}

\begin{abstract}
The aim of the present study was to investigate the role of customer experience quality factors in determining customer loyalty among private hospitals in Pakistan. Customer satisfaction, as a mediator, and familiarity and competitive choices, as moderators, have also been analyzed to intensify the significance of this study. The associations among loyalty, satisfaction, and customer experience quality facets have been comprehensively investigated which have largely been ignored in prior studies despite having considerable significance. Cross-sectional data were gathered using a convenience sampling technique by distributing self-administered questionnaires in 15 major private hospitals. 493 correctly and filled questionnaires, out of 530, were returned indicating that the response rate for this study was 93\%. SPSS-25 and AMOS-22 were used for analyzing the collected data by executing different tests i.e. reliability, correlation, multiple regression, moderated regression, and bootstrapping for mediation. The findings of the study demonstrate significant and positive associations of outcome quality, peer to peer quality, and interaction quality with customer loyalty, and partial mediation of customer satisfaction was also identified among these associations. Additionally, this research has also evidenced the insignificant moderating role of familiarity with the three facets of customer experience quality on customer satisfaction. Moreover, the association between customer satisfaction and loyalty has not been moderated by competitive choices. Future studies may be carried out across diversified cultures to test the generalizability of the outcomes of the present study. Managers and policymakers should consider the significance of customer experience quality facets in order to enhance satisfaction and loyalty among consumers of services provided by the hospital industry.
\end{abstract}

Keywords: Outcome Quality, Peer to Peer Quality, Interaction Quality, Customer Experience Quality, Customer Satisfaction, Customer Loyalty, Competitive Choices, Familiarity, Pakistan

JEL Code: M30

\section{Introduction}

The word loyal is an old French origin word derived from "loial" which means to remain committed or devoted towards a person, country, group, or organization.

${ }^{1}$ Department of Management Sciences, Bahria University Islamabad, Pakistan Corresponding Author: kashif_411@hotmail.com 
Customer loyalty is the commitment of consumers with a company and its offerings to endure long-term affiliation (Jeon \& Jeong, 2017). It can be attributed to customers repurchase intention or endorsement to others indicating that customers not only buy their products themselves but also suggest them to family and friends. Customer loyalty has been proven to play a central role in achieving competitive advantage and it is dependent on various elements, for instance, quality and customer satisfaction (Khan, 2012). Customer satisfaction elucidates the magnitude to which the performance of both products as well as services matches up with the customer expectation level. As the products and services performance copes up with the perception level of a customer, the customer is said to be satisfied or vice versa (Ariff et al., 2012). Numerous researchers have revealed that customer satisfaction has a strong positive association with loyalty (Izogo \& Ogba, 2015). For any organization, customer loyalty is a fundamental determinant for its survival as well as gaining a competitive advantage. As competition is growing day by day almost in every industry, organizations are striving to improve their products and services quality ultimately resulting in increasing customer loyalty (Yeh, 2015). This increase in competition has drawn the interest of numerous researchers to deeply undergo and study customer loyalty (Zimon, 2016).

The Healthcare sector, across the globe, is emerging as a promptly growing and competitive industry. Quality is the main driver for success in the service sector which can create customer satisfaction. Customer quality experience is an overall insight into the service that a particular organization is offering (Halvorsrud et al., 2016). Quality experiences of customers consist of three factors i.e. outcome quality, peer to peer quality, and interaction quality (Lemke et al., 2011). This research has focused on exploring the associations between customer loyalty, customer satisfaction, and customer experience quality in the service industry (hospitals) of Pakistan. Furthermore, the study has also determined the moderating role of familiarity between outcome quality, peer to peer quality, interaction quality, and customer satisfaction while the moderating role of competitive choices between loyalty and customer satisfaction has also been inspected. For this reason, primary data has been gathered using a structured questionnaire from customers belonging to major cities of Pakistan and results have been analyzed using statistical software i.e. SPSS and AMOS. This research attempts to enrich literature pertaining to customer loyalty specifically in the healthcare sector. Limited research studies can be found in marketing literature regarding loyalty and service quality in the healthcare sector of developing economies (Priporas et al., 2017). Hence, the present study may play a vital role as reference material to provide guidelines for upcoming studies. This study is beneficial for improving quality in the healthcare sector by understanding how several approaches to customer experience quality affect loyalty.

\section{Literature Review}

Outcome Quality: Service outcome is a consequence after the service is delivered to the customers and they have some experience with it. Outcome quality takes Sukkur IBA Journal of Management and Business - SIJMB | Vol 7 No. 1 January - June 2020 @ Sukkur IBA University 
place after the service is delivered and it is linked to what service providers actually deliver to the customers. Customer's perception about any offering by an organization is known as outcome quality (Ryu \& Lee, 2017). Zameer et al. (2015) explored that customer satisfaction can be achieved through service quality only when the expected level meets the level perceived by the customer regarding any service. Furthermore, Agus (2019) argued that service outcome has a significant and positive correlation with customer satisfaction in the service sector such as hospitals and financial institutions. It can be hypothesized that:

$\mathbf{H}_{\mathbf{1}}$ : Outcome Quality has an association with Customer Satisfaction.

Choi and Kim (2013) identified a strong correlation between outcome quality and customer loyalty making it an important factor to investigate in the service sector. Moreover, it has also been identified that when the expected quality meets the perception level of customers, they will feel satisfied and this satisfaction may turn out to be a strong driver of loyalty (Alnawas \& Hemsley-Brown, 2019). These arguments lead to the development of the following hypotheses:

$\mathbf{H}_{2}$ : Outcome Quality has an association with Customer Loyalty.

$\mathbf{H}_{3}$ : Customer Satisfaction acts as a mediator between Outcome Quality and Customer Loyalty.

\section{Interaction Quality}

Numerous studies have hypothesized and constructed models for explaining interaction quality (Kim \& Choi, 2013). Interaction quality may be explained as a consumer's experience while interacting with the company's executive when the service is being delivered (Lien et al., 2017). It can be hypothesized that:

$\mathbf{H}_{4}$ : Interaction Quality has an association with Customer Satisfaction.

Few prior studies have confirmed a positive association of interaction quality and customer loyalty (Choi \& Kim, 2013; Alnawas \& Hemsley-Brown, 2019). Additionally, it has also been explored that the company's executives that deliver services directly to the customer can easily drive towards satisfaction and loyalty of customers (Izogo \& Ogba, 2015). Considering hospitals, where it is difficult to evaluate outcome quality during the time of service delivery, interaction quality plays a crucial role. Interacting with the service provider can solve a lot of issues. These arguments lead to the development of the following hypotheses:

$\mathbf{H}_{5}$ : Interaction Quality has an association with Customer Loyalty.

$\mathbf{H}_{6}$ : Customer Satisfaction acts as a mediator between Interaction Quality and Customer Loyalty.

\section{Peer to Peer Quality}

Building strong relationships with customers is considered pivotal by marketing researchers as well as practitioners. These relationships can enhance satisfaction among customers leading to customer loyalty. Satisfied customers have a greater tendency to recommend products and services to others which possibly results in loyalty in the long run. (Lee \& Kim, 2018). It can be hypothesized that:

$\mathbf{H}_{7}$ : Peer to Peer Quality has an association with Customer Satisfaction.

Previous researches suggest that satisfaction and loyalty of customers are strongly interrelated. Both practitioners and philosophers had focused primarily on the 
organization's bond with the customers while largely overlooking relationships among customers (Bowen \& Chen McCain, 2015). Furthermore, it has been determined that satisfied customers of various services tend to recommend these services among their social circle Alnawas \& Hemsley-Brown, 2019). These arguments lead to the development of the following hypotheses:

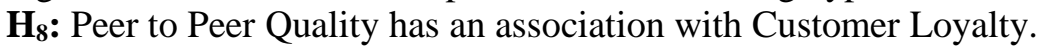

$\mathbf{H}_{9}$ : Customer Satisfaction acts as a mediator between Peer to Peer Quality and Customer Loyalty.

\section{Customer Satisfaction and Loyalty}

Customer loyalty may be described as repeatedly purchasing of products and services while keeping a profitable and successful relationship with a company (Khan, 2012). Attitude and behavior are the two main drivers of loyalty (GuillÈn et al., 2012). The loyalty of customers is of essential concentration for each business element (Chung et al., 2015). A firm's higher authorities' decisions are responsible for making customers loyal thus resulting in generating more sales (Bricci et al., 2016). Emerging businesses or first movers can have a competitive advantage through the loyalty of customers (Saeidi et al., 2015). The literature in marketing is presently concentrating on the change of satisfaction of consumers. The satisfaction of customers is a simple driver to gauge future incomes (Zablah et al., 2016). The satisfaction of customers without much of a stretch can draw consideration of their past customers who have moved towards competitors (Bricci et al., 2016). Customer satisfaction may lead to customer loyalty. These arguments lead to the development of the following hypothesis:

$\mathbf{H}_{10}$ : Customer Satisfaction has an association with Customer Loyalty.

\section{Familiarity as Moderator}

Familiarity may be described as a number of encounters, related to products or services, met by the consumer (Monferrer-Tirado et al., 2016). The familiarity of consumers with products and services has gained the interest of marketing researchers in recent times. As familiarity increases, customers acquire more knowledge and understanding of the features and attributes of the offered services and products (Kim et al., 2016). Moreover, the effect of the three dimensions of customer experience quality on customer satisfaction depends upon familiarity with the people providing services, especially in hotels and hospitals context (Christou et al., 2019). Considering healthcare industry in particular, new patients are unable to judge the services of a hospital as they are not familiar with the outcomes of the services being provided, whereas the patients who are familiar with the operations of the hospital develop a better schema about the result of services on the basis of prior experience. As customers interact with service providers, they can easily develop an understanding about overall service quality. Sometimes, customers can become familiar with the attributes of service, even before the consumption of the service, by interacting with the company's staff. Moreover, whenever customers are familiar with any product or service, there are greater chances that they will recommend it to their friends and peers. These arguments lead to the development of the following hypotheses:

Sukkur IBA Journal of Management and Business - SIJMB | Vol 7 No. 1 January - June 2020 @ Sukkur IBA University 
$\mathbf{H}_{11}$ : Familiarity acts as a moderator between Outcome Quality and Customer Satisfaction.

$\mathbf{H}_{12}$ : Familiarity acts as a moderator between Interaction Quality and Customer Satisfaction.

$\mathbf{H}_{13}$ : Familiarity acts as a moderator between Peer to Peer Quality and Customer Satisfaction.

\section{Competitive Choices as Moderator}

A satisfied and loyal customer is the main focus for any organization in order to generate profits, successfully earn market share, and become a market leader. Competition exists among all firms providing identical services. Organizations providing identical services primarily compete on the basis of price, quality, delivery, flexibility, new technology, innovation, and creativity Cossío-Silva et al., 2016). Competition in a healthcare industry means to reduce the prices and provide the best available services with superior quality. In a developing country where the buying power of the population is low, almost every company competes on price. Similarly, competitive choices may be considered to play a significant moderating role in customer satisfaction and customer loyalty. Expectations for superior quality has created a competitive environment in almost every industry. Quality is the main focus of any organization and quality in the healthcare industry is an issue that cannot be compromised under any circumstances by the customers. Similarly, today hospitals compete over the quality of services they provide. Competition has a substantial influence over creating customer loyalty which may be affected if the price gets low or quality gets high of the competing service provider (Lee \& Kim, 2018). If more intense competitive options are available, it may affect adversely. These arguments lead to the development of the following hypothesis:

$\mathbf{H}_{14}$ : Competitive choices act as a moderator between Customer Satisfaction and Customer Loyalty.

\section{Conceptual Framework}

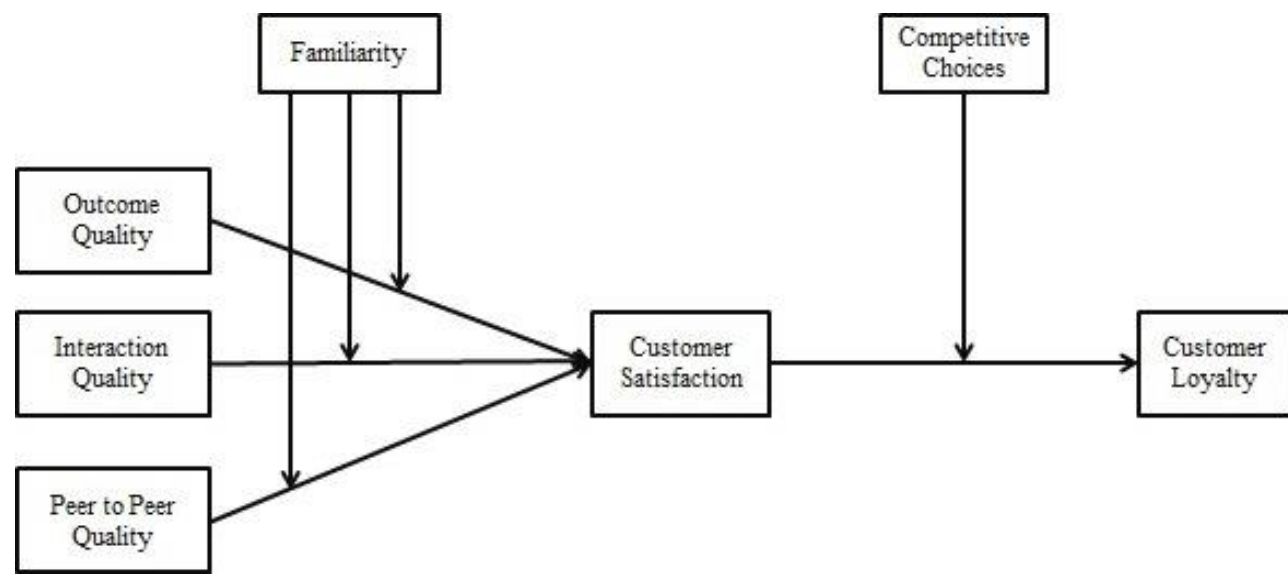

Source: Prepared from the literature review

Sukkur IBA Journal of Management and Business - SIJMB | Vol 7 No. 1 January - June 2020 @ Sukkur IBA University 


\section{Methodology}

Data was gathered using a convenience sampling technique by distributing selfadministered questionnaires among patients of 15 major private hospitals in different cities of Pakistan, under which the impact of the three customer experience quality factors on customer satisfaction and customer loyalty has been studied. Weston and Gore (2006) suggested that for running structural equation modeling, a minimum sample size of 200 is required. To enhance the generalizability of the results, the present study considered a sample size of 530 respondents. After distributing 530 questionnaires, 493 responses were found usable indicating a response rate of $93 \%$. The questionnaire used in this study had thirty-five items. Five items were used for measuring demographic variables, fifteen items for customer loyalty, three items for customer satisfaction, three items for interaction quality, three items for peer to peer quality, three items for outcome quality and three items were used for measuring familiarity. Items of the final questionnaire were adapted from Dick and Basu (1994) in order to measure loyalty, Jamal and Naser (2002) for customer satisfaction, Sharma and Patterson (1999) and Brady and Cronin (2001) for interaction quality, Brady and Cronin (2001) and Lemke et al. (2011) for peer to peer quality, Furguson et al. (1999) and Sharma and Patterson (1999) for outcome quality. For familiarity, items were adapted from Gefen (2000), Gursoy (2001), and Dick et al. (1995). All items were measured through 5 points Likert scale where 1=Strongly Disagree and $5=$ Strongly Agree. Reliability analysis, correlation analysis, confirmatory factor analysis, structural equation modeling, and structural regression were used to analyze the collected data, and SPSS and AMOS software were used for this purpose. Details of execution of analysis have been discussed in the next section.

\section{Results}

The demographic profile of the respondents and correlations analysis of the constructs have been presented first in this section. For testing the proposed hypotheses, the present study has applied structural equation modeling in two steps as recommended by Anderson and Gerbing (1988). At first, the validity of measurement has been established, and then structural regression was run for testing the proposed hypothesis.

\section{Demographics}

Table 1: Demographic Profile of Respondents

\begin{tabular}{|c|c|c|c|c|c|}
\hline Demographic & Characteristics & Frequency & Percent & $\begin{array}{c}\text { Valid } \\
\text { Percent }\end{array}$ & $\begin{array}{c}\text { Cumulative } \\
\text { Percent }\end{array}$ \\
\hline Gender & Male & 340 & $69 \%$ & $69 \%$ & $69 \%$ \\
& Female & 153 & $31 \%$ & $31 \%$ & $100 \%$ \\
\hline Age (in years) & $20-25$ & 386 & $78.3 \%$ & $78.3 \%$ & $78.3 \%$ \\
& $26-30$ & 76 & $15.4 \%$ & $15.4 \%$ & $93.7 \%$ \\
& $31-35$ & 13 & $2.6 \%$ & $2.6 \%$ & $96.3 \%$ \\
\hline & $36-40$ & 6 & $1.3 \%$ & $1.3 \%$ & $97.6 \%$ \\
\hline & $40+$ & 12 & $2.4 \%$ & $2.4 \%$ & $100 \%$ \\
\hline
\end{tabular}




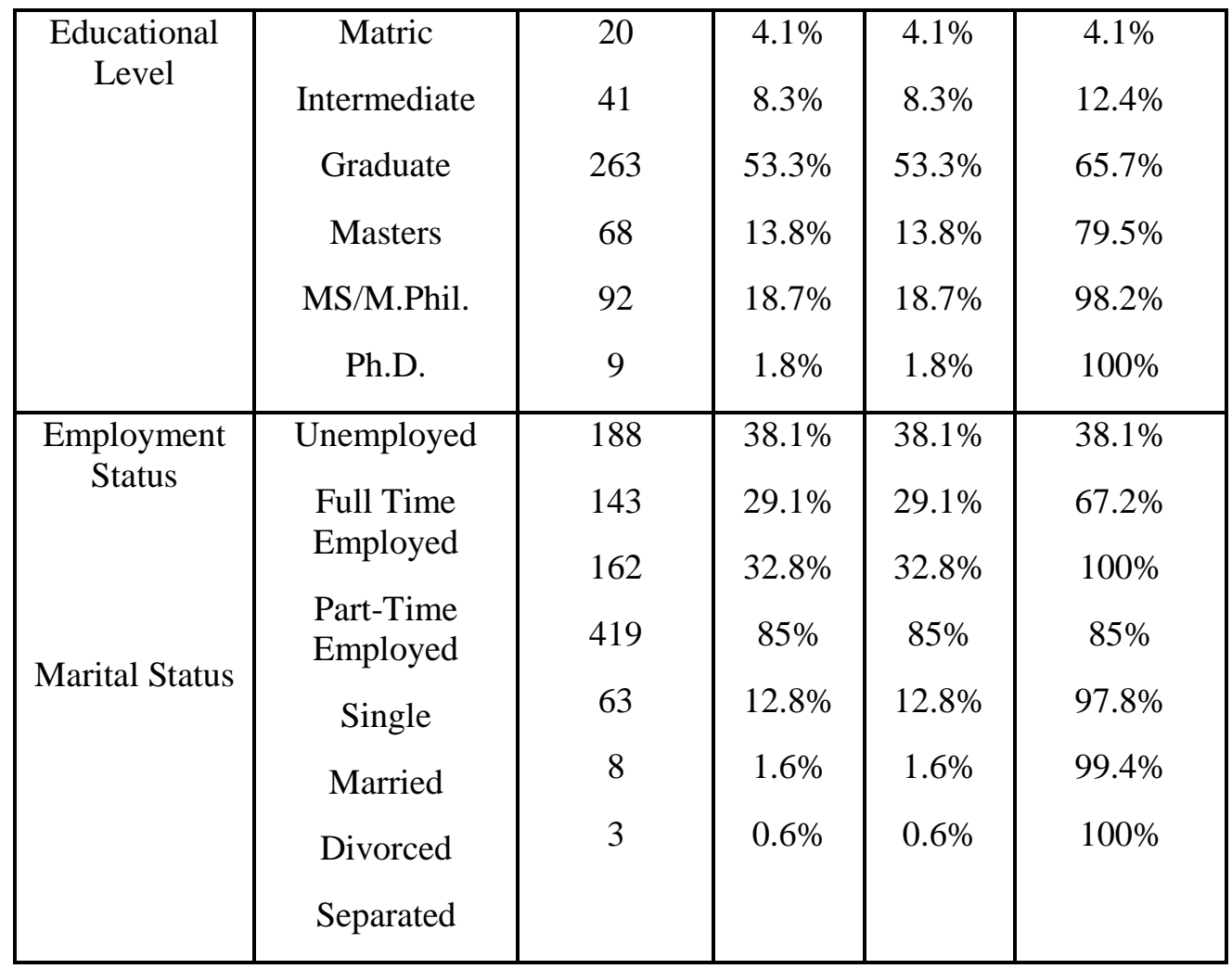

Questionnaires were distributed between both genders consisting of $69 \%$ males and $31 \%$ females. Most of the respondent's age comprised of 20-25 years with a 78.3\% while 26-30 years comprised $15.4 \%$, 31-35 years comprised 2.6\%, 36-40 years comprised $1.3 \%$ and $40+$ years comprised $2.4 \%$ of the total sample size respectively. $53.3 \%$ of the respondents were having a bachelor's degree while $4.1 \%$ were only Matric degree holders. $8.3 \%$ of the respondents were high school graduates. $13.8 \%$ of the respondents were Masters while $18.7 \%$ of the respondents had completed MS/M.Phil. and $1.8 \%$ were Ph.D. degree holders. $38.1 \%$ of the respondents were unemployed, $32.8 \%$ were employed on a part-time basis and only $29.1 \%$ were employed on full-time basis. $85 \%$ of the respondents were single, $12.8 \%$ were married while $1.6 \%$ of the respondents were divorced and $0.6 \%$ were separated. Competitive choices variable was also added in the demographics section of the questionnaire and demanded to be answered with a numerical value. $39.4 \%$ of the respondents answered 0 which indicated that these patients were loyal to the hospital. $27.8 \%$ responded with $2,17.8 \%$ responded with 3-4 and 15\% responded with more than 4 .

\section{Correlation Analysis}

Table 2: Correlation

\begin{tabular}{|l|c|c|c|c|c|}
\hline Variables & CL & CS & OQ & IQ & P2PQ \\
\hline CL & 1 & & & & \\
\hline CS & $.719^{* *}$ & 1 & & & \\
\hline OQ & $.586^{* *}$ & $.651^{* *}$ & 1 & & \\
\hline IQ & $.573^{* *}$ & $.613^{* *}$ & $.577^{* *}$ & 1 & \\
\hline P2PQ & $.508^{* *}$ & $.522^{* *}$ & $.506^{* *}$ & $.582^{* *}$ & 1 \\
\hline
\end{tabular}

$* *$ Correlation is significant at the 0.01 level (2-tailed) 
The results are shown in table-2 specify a positive correlation among all variables. Outcome quality has $65 \%$ correlation with customer satisfaction and $59 \%$ correlation with customer loyalty. Interaction quality has a $61 \%$ correlation with customer satisfaction and $57 \%$ correlation with customer loyalty. Peer to peer quality 52\% correlation with customer satisfaction and 51\% correlation with customer loyalty.

\section{Confirmatory Factor Analysis}

For the reason that all of the items used for measuring the variables considered in the present research, confirmatory factor analysis was deemed as a suitable approach for evaluating the measurement model and this was executed using AMOS version 22. A measurement model, that represents the latent variable model has been assessed before testing the structural model representing hypothesized associations among the constructs (Byrne, 2016). Hair et al. (2014) suggested few model fit indices which include $\chi^{2} / d f$, RMSEA, CFI, TLI, PCFI, and $P N F I$.

Table 3: Measurement Model Fit Indices for Model Evaluation

\begin{tabular}{|c|c|c|c|c|c|c|c|c|}
\hline \multicolumn{3}{|c|}{ Absolute Fit Indices } & \multicolumn{3}{|c|}{ Relative Fit Indices } & \multicolumn{3}{|c|}{$\begin{array}{l}\text { Parsimonious Fit } \\
\text { Indices }\end{array}$} \\
\hline Test & $\begin{array}{l}\text { Suggest } \\
\text { ed } \\
\text { Value }\end{array}$ & $\begin{array}{c}\text { Obtain } \\
\text { ed } \\
\text { Value }\end{array}$ & Test & $\begin{array}{l}\text { Suggest } \\
\text { ed } \\
\text { Value }\end{array}$ & $\begin{array}{c}\text { Obtain } \\
\text { ed } \\
\text { Value }\end{array}$ & $\begin{array}{c}\text { Tes } \\
\mathrm{t}\end{array}$ & $\begin{array}{c}\text { Suggest } \\
\text { ed } \\
\text { Value }\end{array}$ & $\begin{array}{c}\text { Obtain } \\
\text { ed } \\
\text { Value }\end{array}$ \\
\hline $\begin{array}{l}\text { CMIN/ } \\
\text { DF }\end{array}$ & $<3$ & 2.132 & CFI & $>.90$ & .942 & $\begin{array}{l}\text { PN } \\
\text { FI }\end{array}$ & $>.50$ & .812 \\
\hline $\begin{array}{c}\text { RMSE } \\
\text { A }\end{array}$ & $<.08$ & 0.067 & TLI & $>.90$ & .935 & $\begin{array}{l}\mathrm{PC} \\
\mathrm{FI}\end{array}$ & $>.50$ & .838 \\
\hline & & & $\begin{array}{c}\mathrm{AG} \\
\mathrm{FI}\end{array}$ & $>.80$ & .840 & & & \\
\hline
\end{tabular}

Table-3 illustrates model evaluation results and it can be observed that all values are suitable as per suggested cut-off criteria indicating good-fit of sample data. The model fit requirements from absolute, relative, and parsimonious fit indexes have been satisfied. Since no model modification was required, data analysis was proceeded towards analyzing the structural model.

\section{Reliability and Validity Analysis}

In order to measure reliability, composite reliability for all variables was measured and it was observed to be greater than 0.7 as recommended by Hair et al. (2010). Therefore, it can be inferred that construct reliability has been established. Furthermore, convergent and discriminant validity was also established. As a measure of convergent validity, the average variance explained (AVE) was computed and this value should be 0.50 or more. As measures of discriminant validity, maximum shared variance (MSV), and average shared variance (ASV) were computed and these values should be less than the AVE value of that particular construct (Hair et al., 2010).

Table 4: Measures for Reliability and Validity

\begin{tabular}{|l|c|c|c|c|}
\hline \multicolumn{1}{|c|}{ Construct } & CR & AVE & MSV & ASV \\
\hline Outcome Quality (OQ) & .75 & .56 & .51 & .50 \\
\hline Interaction Quality (IQ) & .81 & .59 & .53 & .55 \\
\hline
\end{tabular}

Sukkur IBA Journal of Management and Business - SIJMB | Vol 7 No. 1 January - June 2020 @ Sukkur IBA University 


\begin{tabular}{|l|c|c|c|c|}
\hline Peer to Peer Quality (P2PQ) & .79 & .61 & .56 & .53 \\
\hline Customer Satisfaction (CS) & .73 & .54 & .50 & .52 \\
\hline Familiarity (FAM) & .78 & .57 & .51 & .51 \\
\hline Competitive Choices (CC) & .79 & .54 & .52 & .51 \\
\hline Customer Loyalty (CL) & .85 & .63 & .52 & .56 \\
\hline
\end{tabular}

$\mathrm{CR}=$ Composite Reliability, AVE=Average Variance Extracted=AVE, MSV=Maximum Shared Variance, ASV=Average Shared Variance. Cut off: $\mathrm{CR}>0.7$; AVE>.50; AVE>MSV; AVE>ASV

It can be observed from table-4 that all measures, calculated from the data collected, fall within the suggested levels for determining reliably, convergent validity as well as discriminant validity.

\section{Structural Model Analysis}

The hypothesis of the present research has been tested in the structural model. In the first run, model fit was achieved as all indices were as per suggested criteria $(\mathrm{CMIN} / \mathrm{df}=2.027, \mathrm{RMSEA}=0.072 \mathrm{AGFI}=0.816, \mathrm{CFI}=0.925$, TLI=0.920). Firstly, all the direct relationships were examined using regression analysis. The mediation and moderation analysis was executed afterward.

Table 5: Direct Effects

\begin{tabular}{|l|c|c|c|c|c|}
\hline \multicolumn{1}{|c|}{ Path } & $\begin{array}{c}\text { Standardized } \\
\text { Beta }\end{array}$ & $\begin{array}{c}\text { Standard } \\
\text { Error }\end{array}$ & CR & P-Value & Accept/Reject \\
\hline OQ $\rightarrow$ CS & .346 & .053 & 8.505 & .000 & Accepted \\
\hline IQ $\rightarrow$ CS & .358 & .055 & 8.295 & .000 & Accepted \\
\hline P2PQ $\rightarrow$ CS & .063 & .056 & 2.552 & .021 & Accepted \\
\hline OQ $\rightarrow$ CL & .241 & .040 & 5.371 & .000 & Accepted \\
\hline IQ $\rightarrow$ CL & .230 & .041 & 4.950 & .003 & Accepted \\
\hline P2PQ $\rightarrow$ CL & .210 & .041 & 4.786 & .005 & Accepted \\
\hline $\mathrm{CS} \rightarrow$ CL & .403 & .039 & 9.157 & .001 & Accepted \\
\hline
\end{tabular}

Table-5 illustrates the regression results of direct relationships. Outcome quality $(\beta=.241, p<.05)$, interaction quality $(\beta=.230, \mathrm{p}<.05)$ and peer to peer quality $(\beta=.210, p<.05)$ have a significant and positive impact over customer loyalty. Furthermore, outcome quality $(\beta=.346, \mathrm{p}<.05)$, interaction quality $(\beta=.358, \mathrm{p}<.05)$ and peer to peer quality $(\beta=.063, \mathrm{p}<.05)$ have a significant and positive impact over customer satisfaction. Lastly, customer satisfaction $(\beta=.403, p<.05)$ has a significant and positive impact on customer loyalty. Additionally, it was observed that all the independent variables of the study appeared to have explained around $32.1 \%$ variance in customer loyalty. The value of $\mathrm{R}^{2}$, which was .321 , indicated that the model is effective. Therefore, hypotheses $\mathrm{H}_{1}, \mathrm{H}_{2}, \mathrm{H}_{4}, \mathrm{H}_{5}, \mathrm{H}_{7}, \mathrm{H}_{8}$, and $\mathrm{H}_{10}$ have been accepted.

\section{Mediation Analysis}

As suggested by Preacher and Hayes (2008), the mediation analysis was executed using the bootstrapping method since it is a non-parametric technique and very effective for measuring indirect effects. AMOS was used for performing the mediation analysis using 5000 bootstrap sample. 
Table 6: Mediation Analysis Results

\begin{tabular}{|c|c|c|c|c|c|c|}
\hline \multicolumn{7}{|c|}{ Customer Loyalty } \\
\hline \multirow[b]{2}{*}{$\begin{array}{c}\text { Variables } \\
\text { and Effects }\end{array}$} & \multirow[b]{2}{*}{$\begin{array}{l}\text { Point of } \\
\text { Estimate }\end{array}$} & \multirow[b]{2}{*}{ SE } & \multicolumn{2}{|c|}{ BC 95\% CI } & \multirow[b]{2}{*}{$\begin{array}{c}\text { P- } \\
\text { Value }\end{array}$} & \multirow[b]{2}{*}{$\begin{array}{c}\text { Mediation } \\
\text { Observed }\end{array}$} \\
\hline & & & Lower & Upper & & \\
\hline \multicolumn{7}{|c|}{ Mediator: Customer Satisfaction } \\
\hline \multicolumn{6}{|c|}{ Outcome Quality } & \multirow{4}{*}{ Partial } \\
\hline Total Effect & .203 & .029 & .024 & .313 & .000 & \\
\hline $\begin{array}{l}\text { Direct } \\
\text { Effect }\end{array}$ & .146 & .026 & .072 & .338 & .001 & \\
\hline $\begin{array}{l}\text { Indirect } \\
\text { Effect }\end{array}$ & .057 & .019 & .101 & .282 & .000 & \\
\hline \multicolumn{6}{|c|}{ Interaction Quality } & \multirow{4}{*}{ Partial } \\
\hline Total Effect & .193 & .027 & .022 & .311 & .002 & \\
\hline $\begin{array}{l}\text { Direct } \\
\text { Effect }\end{array}$ & .138 & .024 & .042 & .276 & .021 & \\
\hline $\begin{array}{l}\text { Indirect } \\
\text { Effect }\end{array}$ & .055 & .018 & .086 & .325 & .004 & \\
\hline \multicolumn{6}{|c|}{ Peer to Peer Quality } & \multirow{4}{*}{ Partial } \\
\hline Total Effect & .176 & .026 & .029 & .302 & .001 & \\
\hline $\begin{array}{l}\text { Direct } \\
\text { Effect }\end{array}$ & .126 & .023 & .056 & .331 & .010 & \\
\hline $\begin{array}{l}\text { Indirect } \\
\text { Effect }\end{array}$ & .050 & .016 & .091 & .244 & .003 & \\
\hline
\end{tabular}

$\mathrm{BC}=$ Bias Corrected, $\mathrm{CI}=$ Confidence Interval

The results with customer satisfaction as a mediator have been summarized in table-6. It can be observed that customer satisfaction partially mediates the association among the independent and dependent variables of the study. For outcome quality, the total effect $(\beta=.203, p<.05)$, direct effect $(\beta=.146, p<.05)$ as well as specific indirect effect $(\beta=.057, p<.05)$ were statistically significant and non-zero. For interaction quality, the total effect $(\beta=.193, p<.05)$, direct effect $(\beta=.138, p<.05)$ as well as specific indirect effect $(\beta=.055, p<.05)$ were statistically significant and non-zero. For peer to peer quality, the total effect $(\beta=.176, p<.05)$, direct effect $(\beta=.126, p<.05)$ as well as specific indirect effect $(\beta=.050, p<.05)$ were statistically significant and non-zero. In all cases, the significance of the direct path was not influenced by the introduction of the mediator indicating partial mediation. Therefore, hypotheses $\mathrm{H}_{3}, \mathrm{H}_{6}$, and $\mathrm{H}_{9}$ have been accepted.

\section{Moderation Analysis}

For testing the moderating effects, four separate models were developed. The aim was to identify the influence of competitive choices between the association of customer satisfaction and loyalty and to identify the influence of familiarity between the association of three independent variables and the dependent variable of the study. The moderation effects have been estimated using interaction terms (Holmbeck, 1997). These interaction terms were obtained by multiplying scores of independent variables and moderators. Standardized scores of the constructs have been considered for this purpose and the dependent variable has been regressed on 
the independent variable, the moderating variable as well as the interaction term. Aiken, West, and Reno (1991) recommended using standardized values of constructs for avoiding issues pertaining to multicollinearity. Consequently, a significant correlation among these constructs and interaction terms may not result in creating any problem in order to test moderating variables.

Table 7: Moderation Analysis Results

\begin{tabular}{|c|c|c|c|c|c|}
\hline \multicolumn{6}{|c|}{ Customer Loyalty } \\
\hline Variables and Effects & $\begin{array}{l}\text { Point of } \\
\text { Estimate }\end{array}$ & $\mathbf{S E}$ & $\mathbf{C R}$ & P-Value & $\begin{array}{c}\text { Moderation } \\
\text { Observed }\end{array}$ \\
\hline \multicolumn{6}{|l|}{ Moderator: Familiarity } \\
\hline \multicolumn{5}{|l|}{ Outcome Quality } & \multirow{4}{*}{$\begin{array}{c}\text { No } \\
\text { Moderation }\end{array}$} \\
\hline $\mathrm{ZOQ} \rightarrow \mathrm{ZCL}$ & .296 & .037 & 5.179 & .000 & \\
\hline $\mathrm{ZFAM} \rightarrow \mathrm{ZCL}$ & .107 & .021 & 2.110 & .025 & \\
\hline ZOQ x ZFAM $\rightarrow$ ZCL & .035 & .011 & 1.709 & .980 & \\
\hline \multicolumn{5}{|l|}{ Interaction Quality } & \multirow{4}{*}{$\begin{array}{c}\text { No } \\
\text { Moderation }\end{array}$} \\
\hline $\mathrm{ZIQ} \rightarrow \mathrm{ZCL}$ & .282 & .034 & 4.991 & .000 & \\
\hline $\mathrm{ZFAM} \rightarrow \mathrm{ZCL}$ & .111 & .023 & 2.209 & .031 & \\
\hline$\overline{Z I Q} \times \mathrm{ZFAM} \rightarrow \mathrm{ZCL}$ & .040 & .013 & 1.711 & .889 & \\
\hline \multicolumn{5}{|l|}{ Peer to Peer Quality } & \multirow{4}{*}{$\begin{array}{c}\text { No } \\
\text { Moderation }\end{array}$} \\
\hline $\mathrm{ZP} 2 \mathrm{PQ} \rightarrow \mathrm{ZCL}$ & .258 & .030 & 4.627 & .000 & \\
\hline $\mathrm{ZFAM} \rightarrow \mathrm{ZCL}$ & .118 & .024 & 2.348 & .016 & \\
\hline ZP2PQ x ZFAM $\rightarrow$ ZCL & .043 & .014 & 1.720 & .768 & \\
\hline \multicolumn{6}{|c|}{ Moderator: Competitive Choices } \\
\hline \multicolumn{5}{|c|}{ Customer Satisfaction } & \multirow{4}{*}{$\begin{array}{c}\text { No } \\
\text { Moderation }\end{array}$} \\
\hline $\mathrm{ZCS} \rightarrow \mathrm{ZCL}$ & .492 & .054 & 10.904 & .001 & \\
\hline $\mathrm{ZCC} \rightarrow \mathrm{ZCL}$ & .093 & .019 & 2.010 & .033 & \\
\hline$\overline{Z C S} \times \mathrm{ZCC} \rightarrow \mathrm{ZCL}$ & .050 & .016 & 1.734 & .771 & \\
\hline
\end{tabular}

$\mathrm{Z}=$ Standardized values

The results summarized in table-7 signpost that neither familiarity nor competitive choices play a moderating role in the proposed model. The relationships of independent variables with the dependent variable are significant and the relationships of moderators with dependent variables are also significant. However, in all four cases, the relationships of interaction terms ( $p>0.05)$ with the dependent variable are not significant. This indicates that competitive choices cannot be considered as a moderator between the association of customer satisfaction and loyalty. Similarly, familiarity cannot be considered as a moderator between the association of outcome quality, interaction quality, and peer to peer quality and customer loyalty. Therefore, hypotheses $\mathrm{H}_{11}, \mathrm{H}_{12}, \mathrm{H}_{13}$, and $\mathrm{H}_{14}$ have been rejected.

\section{Discussion}

Quality is the main factor of success in any industry. Providing superior quality can make any sector or organization the market leader. Continuous improvement, enhancement, and change according to the market needs can successfully drive an organization towards customer satisfaction which is considered as the fundamental determinant of loyalty and an essential element of success. Basically, a firm's 
profitability depends upon both of these factors. And both these variables depend on a number of factors out of which quality is one factor.

A hypothesis proposed in this study was about outcome quality impacting customer loyalty. The findings recorded a significant and positive association between the two variables. The findings are compatible with previous studies' findings (Choi \& Kim, 2013; Alnawas \& Hemsley-Brown, 2019). Previously Hsieh and Hiang (2004) found a strong connection between satisfaction and outcome quality. Another hypothesis about the mediating effect of customer satisfaction between outcome quality and loyalty was developed. The findings recorded a significant and positive association between the two variables. The association between outcome quality and loyalty was partially mediated by satisfaction.

A hypothesis about the existence of a positive relationship among outcome quality and customer satisfaction was developed. Findings recorded a significant and positive association between the two variables. Studies conducted in the past proved that satisfaction and outcome quality are positively correlated (Choi \& Kim, 2013; Alnawas \& Hemsley-Brown, 2019). Another hypothesis of the study was about the positive association between interaction quality and loyalty. Findings recorded a significant and positive association between the two variables. Few previous studies in a similar domain have found a positive linkage of interaction quality with customer loyalty (Choi \& Kim, 2013).

Another hypothesis about the mediating effect of customer satisfaction among interaction quality and customer loyalty was developed. Findings recorded a significant and positive association between the two variables. Satisfaction proved to partially mediate the association between outcome quality and loyalty. Few marketing research studies have found a positive correlation between satisfaction, loyalty, and interaction quality (Choi \& Kim, 2013; Alnawas \& Hemsley-Brown, 2019). Another hypothesis about the linkage between interaction quality and customer satisfaction was developed. Findings recorded a significant and positive association between the two variables. Hsieh and Hiang (2004) found a weak but positive connotation among satisfaction and interaction quality. Choi and Kim (2013) and Alnawas and Hemsley-Brown (2019) also identified significant and positive connotation among satisfaction and interaction quality.

A hypothesis for association among peer to peer quality and loyalty was developed. Findings recorded a significant and positive association between the two variables. Previous studies carried out in the same scenario stated that a limited number of interactions with other customers who use the service of the same healthcare service provider are difficult to assess in a limited contact (Ostrom \& Iacobucii, 1995; Wu \& Cheng, 2019). Another hypothesis concerning about mediating effect of customer satisfaction among peer to peer quality and loyalty was developed. Findings recorded a significant and positive association between the two variables. Satisfaction partially mediated the bond between loyalty and outcome quality. Generally, whenever customers recommend other customers a service for usage, customer satisfaction will be developed resulting in the increase of customer loyalty.

A hypothesis for connection among peer to peer quality and satisfaction was developed. Findings recorded a significant and positive association between the two variables. Previously Choi and Kim (2013) found a positive correlation among satisfaction and peer to peer quality. This factor has been unnoticed by many researchers and academicians (Harris \& Baron, 2004). Numerous studies discovered strong associations between customer's interaction with each other to be an impactful determinant of customer satisfaction which either creates satisfaction or dissatisfaction (Martin \& Pranter, 1989; Moore et al., 2005; Choi \& Kim, 2013). Moore et al. (2005) also investigated customer to customer 
communications considering other service provider contexts stated that infinite contacts are required in order to be able to recommend any service for usage to other customers.

One of the hypotheses of the study was that familiarity moderates the association between outcome quality and satisfaction. Outcomes have depicted a positive connection of familiarity among satisfaction and outcome quality. Few prior researches have acknowledged positive relation among satisfaction and outcome quality (Choi \& Kim, 2013). Generally, whenever the customer is aware of the outcomes of a service, the familiarity with the service provider will increase thus resulting in the increase of customer satisfaction. A hypothesis of this research was about the moderating effect of familiarity among interaction quality and satisfaction. The findings recorded a positive connection of familiarity between satisfaction and interaction quality. It is a general understanding that whenever the service provider personnel will be familiar with the services, the personnel can easily develop customer satisfaction by answering different queries of the customer. Another hypothesis of this research was about the moderating effect of familiarity among peer to peer quality and customer satisfaction. Findings indicated a positive connotation of familiarity between satisfaction and interaction quality. Customers mostly prefer to ask their friends, peers, or other customers about their experience with a specific service. A customer can seek advice from other customers which can greatly influence satisfaction or dissatisfaction.

A hypothesis of relationship exists between satisfaction and loyalty was developed. Findings recorded a significant and positive association between the two variables. Numerous researchers have found and proved that strong associations exist between loyalty and satisfaction (Meesala \& Paul, 2018). Loyalty is identified as one of the outcomes of customer satisfaction (Meesala \& Paul, 2018). It is a general understanding that whenever a customer is satisfied, the loyalty for that specific product or service will increase. Another hypothesis of this research was about the moderating effect of competitive choices among customer satisfaction and customer loyalty. Moderated regression analysis results depicted that competitive choices did not moderate the association between loyalty and satisfaction. A negative relationship exists here which means that people are reluctant to experience different brands when it is a matter of health.

\section{Conclusion}

The present study intended to identify the impact of outcome quality, peer to peer quality, and interaction quality over customer satisfaction. The results demonstrated the positive impact of all the independent variables i.e. outcome quality, peer to peer quality, and interaction quality on customer satisfaction. Data were analyzed through running different tests i.e. reliability, correlation, multiple regression, moderated regression. SPSS software version 25 was used for running these tests. For mediation through the bootstrapping method, AMOS software version 22 was used. Outcome quality had a positive association with customer satisfaction $(\beta=.346)$ while the association of interaction quality with customer satisfaction was found positive but less than outcome quality $(\beta=.358)$. However, peer to peer quality also had a positive connection with satisfaction but this relationship was found weaker as compared to other variables $(\beta=.063)$. Hence it is proved from the findings that customer satisfaction is strongly influenced by outcome quality

Another important aim of this research was to identify the impact of the three customer experience quality factors over loyalty. Outcomes have demonstrated the positive impact of all the independent variables i.e. outcome quality, peer to peer quality, and interaction quality on loyalty. Outcome quality had positive as well as significant bond with loyalty $(\beta=.241)$ whereas connection of interaction quality 
with customer loyalty was found positive but less than outcome quality $(\beta=.230)$. However, peer to peer quality also had a positive association with customer loyalty but the relationship was found weaker with respect to other variables $(\beta=$ .210). Hence it is proved from the findings that outcome quality is a predominant determinant to strongly influence customer loyalty. The present study also intended to identify the influence of satisfaction over loyalty. Outcomes indicated a positive effect $(\beta=.403)$ indicating a strong relationship among two variables.

The current research also looked into customer satisfaction as a mediating variable between interaction quality, outcome quality, peer to peer quality, and loyalty. Results depicted partial mediation among independent and dependent variables. Outcome quality $(\beta=.203)$ is a predominant determinant that positively affects both satisfaction as well as loyalty. Interaction quality $(\beta=.193)$ positively influences satisfaction. Peer to peer quality $(\beta=.176)$ has a positive but weaker link with satisfaction and loyalty. Outcome quality had a stronger positive bond with satisfaction and loyalty.

The present research examined familiarity as a moderator between interaction quality, outcome quality, peer to peer quality, and satisfaction. It was found that familiarity does play a significant moderating role between interaction quality, outcome quality, peer to peer quality, and satisfaction. Results have identified a positive association of familiarity between outcome quality and satisfaction while a positive association of familiarity between interaction quality and customer satisfaction exists as well. However, peer to peer quality had a positive association with familiarity influencing customer satisfaction. Peer to peer quality had the weakest relationship in this context. This research also identified the moderating role of competitive choices among satisfaction and loyalty. However, outcomes depicted that there is no moderating role of competitive choices so this hypothesis was rejected.

\section{Theoretical Contributions and Practical Implications}

The present study has contributed towards existing literature in a unique aspect by considering customer satisfaction as a mediating variable among dimensions of service quality and customer loyalty. The role of service quality is primarily under looked in hospitals and for this reason, literature pertaining to this domain is scarce. The study has uniquely explained the factors that can play a significant role in determining loyalty among consumers of hospital services and there are few factors having an insignificant role in this domain. This opens up avenues for further elaboration on this phenomenon by extending the present study model and studying it in diversified cultures and contexts. The attempt to nourish the scarce literature regarding service quality in the hospital sector is the most significant theoretical contribution of the present research.

The findings of this research identified that improvement in performance-based activities i.e. outcome quality, peer to peer quality, and interaction quality can easily lead to customer satisfaction which plays an imperative role in determining customer loyalty. Considering the outcomes of this study, managers should put the effort into satisfying the customers and managing better relationships with them by providing superior service quality to gain a competitive advantage in the marketplace. All three facets of customer experience quality must be taken into consideration while policy-making for effective management and creating loyalty among customers of private hospitals. Customer satisfaction is the key to survival in this industry therefore, managers and policymakers must incorporate strategies focusing on satisfying their customers and the customer experience quality facets can significantly aid them in this regard. 


\section{Limitations and Directions for Future Research}

Considering time limitations, data was collected from 530 respondents out of which 493 respondent's data is in a useable form. Future studies could precede this work to the overall Asian healthcare sector. Future researchers should explore other facets of customer experience quality else than the factors considered in this research. The same facets of customer experience quality can also be studied in other sectors as well. Nevertheless, the moderating role of competitive choices between satisfaction and loyalty was introduced that can be examined across other cultures and sectors as well. As in the case of this study, the hypothesis for this variable was rejected but may vary in other contexts. Future studies may examine this association to reevaluate the moderating role of the proposed variables in different industries and cultural settings as well.

\section{References}

Abrar, K. (2018). Impact of Augmented Reality on Consumer Purchase Intention with the Mediating role of Customer Brand Engagement: Moderating role of Interactivity in Online Shopping. Bahria University Journal of Management \& Technology, 1(2), 64-80.

Abrar, K. (2019). Impact of Customization and Customer Engagement on Brand Love with the Mediating role of Brand Performance. Evidence from Hotel Industry of Pakistan. Sukkur IBA Journal of Management and Business, 6(1), 66-86.

Agus, A. (2019). Service Quality, Customer Satisfaction, Location and Customer Loyalty: Mediation and Moderation Analyses. International Journal of Recent Technology and Engineering, 8(2 Special Issue), 652-662.

Aiken, L. S., West, S. G., \& Reno, R. R. (1991). Multiple regression: Testing and interpreting interactions. Sage.

Alnawas, I., \& Hemsley-Brown, J. (2019). Examining the key dimensions of customer experience quality in the hotel industry. Journal of Hospitality Marketing \& Management, 28(7), 833-861.

Anderson, J. C., \& Gerbing, D. W. (1988). Structural equation modeling in practice: A review and recommended two-step approach. Psychological bulletin, 103(3), 411423.

Ariff, M. S. B. M., Fen, H. S., Zakuan, N., Ishak, N., \& Ismail, K. (2012). RELATIONSHIP BETWEEN CUSTOMERS'PERCEIVED VALUES, SATISFACTION AND LOYALTY OF MOBILE PHONE USERS. Review of Integrative Business and Economics Research, 1(1), 126-135.

Bowen, J. T., \& Chen McCain, S. L. (2015). Transitioning loyalty programs: A commentary on "the relationship between customer loyalty and customer satisfaction". International Journal of Contemporary Hospitality Management, 27(3), 415-430.

Brady, M. K., \& Cronin Jr, J. J. (2001). Some new thoughts on conceptualizing perceived service quality: a hierarchical approach. Journal of marketing, 65(3), 34-49.

Bricci, L., Fragata, A., \& Antunes, J. (2016). The effects of trust, commitment and satisfaction on customer loyalty in the distribution sector. Journal of Economics, Business and Management, 4(2), 173-177.

Byrne Barbara, M. (2016). Structural equation modeling with AMOS: basic concepts, applications, and programming. New York: Multivariate Application Series, Routledge.

Choi, B. J., \& Kim, H.-S. (2013). The impact of outcome quality, interaction quality, and peer-to-peer quality on customer satisfaction with a hospital service. Managing Service Quality: An International Journal, 23(3), 188-204.

Christou, P., Avloniti, A., \& Farmaki, A. (2019). Guests' perceptions of emotionally expressive and non-expressive service providers within the hospitality context. International Journal of Hospitality Management, 76, 152-162.

Chung, K. H., Yu, J. E., Choi, M. G., \& Shin, J. I. (2015). The effects of CSR on customer satisfaction and loyalty in China: the moderating role of corporate image. Journal of Economics, Business and Management, 3(5), 542-547.

Sukkur IBA Journal of Management and Business - SIJMB | Vol 7 No. 1 January - June 2020 @ Sukkur IBA University 
Cossío-Silva, F. J., Revilla-Camacho, M. Á., Vega-Vázquez, M., \& Palacios-Florencio, B. (2016). Value co-creation and customer loyalty. Journal of Business Research, 69(5), 1621-1625.

Hair, J. F., Anderson, R. E., Babin, B. J., \& Black, W. C. (2010). Multivariate Data Analysis. Upper Saddle River, NJ: Pearson.

Hair, J. F., Gabriel, M., \& Patel, V. (2014). AMOS covariance-based structural equation modeling (CB-SEM): Guidelines on its application as a marketing research tool. Brazilian Journal of Marketing, 13(2), 44-55.

Halvorsrud, R., Kvale, K., \& Følstad, A. (2016). Improving service quality through customer journey analysis. Journal of service theory and practice, 26(6), 840-867.

Harris, K., \& Baron, S. (2004). Consumer-to-consumer conversations in service settings. Journal of Service Research, 6(3), 287-303.

Ho, R., Huang, L., Huang, S., Lee, T., Rosten, A., \& Tang, C. S. (2009). An approach to develop effective customer loyalty programs: The VIP program at T\&T Supermarkets Inc. Managing Service Quality: An International Journal, 19(6), 702720.

Holmbeck, G. N. (1997). Toward terminological, conceptual, and statistical clarity in the study of mediators and moderators: Examples from the child-clinical and pediatric psychology literatures. Journal of consulting and clinical psychology, 65(4), 599610.

Hsieh, Y.-C., \& Hiang, S.-T. (2004). A study of the impacts of service quality on relationship quality in search-experience-credence services. Quality control and applied statistics, 49(6), 687-688.

Izogo, E. E., \& Ogba, I. E. (2015). Service quality, customer satisfaction and loyalty in automobile repair services sector. International Journal of Quality \& Reliability Management, 32(3), 250-269.

Jamal, A., \& Naser, K. (2002). Customer satisfaction and retail banking: an assessment of some of the key antecedents of customer satisfaction in retail banking. International Journal of Bank Marketing, 20(4), 146-160.

Jeon, M. M., \& Jeong, M. (2017). Customers' perceived website service quality and its effects on e-loyalty. International Journal of Contemporary Hospitality Management, 29(1), 438-457.

Khan, I. (2012). Impact of customers satisfaction and customers retention on customer loyalty. International Journal of Scientific \& Technology Research, 1(2), 106-110.

Kim, H. S., \& Choi, B. (2016). The effects of three customer-to-customer interaction quality types on customer experience quality and citizenship behavior in mass service settings. Journal of Services Marketing, 30(4), 384-397.

Kim, S., Park, G., Lee, Y., \& Choi, S. (2016). Customer emotions and their triggers in luxury retail: Understanding the effects of customer emotions before and after entering a luxury shop. Journal of Business Research, 69(12), 5809-5818.

Lee, S., \& Kim, D. Y. (2018). The effect of hedonic and utilitarian values on satisfaction and loyalty of Airbnb users. International Journal of Contemporary Hospitality Management, 30(3), 1332-1351.

Lemke, F., Clark, M., \& Wilson, H. (2011). Customer experience quality: an exploration in business and consumer contexts using repertory grid technique. Journal of the academy of marketing science, 39(6), 846-869.

Lien, C. H., Cao, Y., \& Zhou, X. (2017). Service quality, satisfaction, stickiness, and usage intentions: An exploratory evaluation in the context of WeChat services. Computers in Human Behavior, 68, 403-410.

Meesala, A., \& Paul, J. (2018). Service quality, consumer satisfaction and loyalty in hospitals: Thinking for the future. Journal of Retailing and Consumer Services, 40(July), 261-269.

Martin, C. L., \& Pranter, C. A. (1989). Compatibility management: customer-to-customer relationships in service environments. Journal of Services Marketing, 3(3), 5-15.

Monferrer-Tirado, D., Estrada-Guillén, M., Fandos-Roig, J. C., Moliner-Tena, M. Á., \& Sanchez Garcia, J. (2016). Service quality in bank during an economic crisis. International Journal of Bank Marketing, 34(2), 235-259. 
Moore, R., Moore, M. L., \& Capella, M. (2005). The impact of customer-to-customer interactions in a high personal contact service setting. Journal of Services Marketing, 19(7), 482-491.

Ostrom, A., \& Lacobucci, D. (1995). Consumer trade-offs and the evaluation of services. Journal of marketing, 59(1), 17-28.

Preacher, K. J., \& Hayes, A. F. (2008). Asymptotic and resampling strategies for assessing and comparing indirect effects in multiple mediator models. Behavior research methods, 40(3), 879-891.

Priporas, C. V., Stylos, N., Vedanthachari, L. N., \& Santiwatana, P. (2017). Service quality, satisfaction, and customer loyalty in Airbnb accommodation in Thailand. International Journal of Tourism Research, 19(6), 693-704.

Ryu, K., \& Lee, J. S. (2017). Examination of restaurant quality, relationship benefits, and customer reciprocity from the perspective of relationship marketing investments. Journal of Hospitality \& Tourism Research, 41(1), 66-92.

Saeidi, S. P., Sofian, S., Saeidi, P., Saeidi, S. P., \& Saaeidi, S. A. (2015). How does corporate social responsibility contribute to firm financial performance? The mediating role of competitive advantage, reputation, and customer satisfaction. Journal of business research, 68(2), 341-350.

Weston, R., \& Gore Jr, P. A. (2006). A brief guide to structural equation modeling. The counseling psychologist, 34(5), 719-751.

Wu, H. C., \& Cheng, C. C. (2019). An empirical analysis of green experiential loyalty: A case study. Journal of International Food \& Agribusiness Marketing, 31(1), 69-105.

Yeh, Y. P. (2015). Corporate social responsibility and service innovation on customer loyalty: An empirical investigation in wealth management services. International Journal of Bank Marketing, 33(6), 823-839.

Zablah, A. R., Carlson, B. D., Donavan, D. T., Maxham III, J. G., \& Brown, T. J. (2016). A cross-lagged test of the association between customer satisfaction and employee job satisfaction in a relational context. Journal of Applied Psychology, 101(5), 743.

Zameer, H., Tara, A., Kausar, U., \& Mohsin, A. (2015). Impact of service quality, corporate image and customer satisfaction towards customers' perceived value in the banking sector in Pakistan. International journal of bank marketing, 33(4), 442456.

Zimon, D. (2016). Influence of quality management system on improving processes in small and medium-sized organizations. Calitatea, 17(150), 61-64. 